\title{
ПИТАННЯ ПРАВОВОГО ВІДМЕЖУВАННЯ ДИФАМАЦІЇ ВІД ДОПУСТИМОЇ КРИТИКИ В МАС-МЕДІА
}

Гуйван П. Д.

\begin{abstract}
Запропонована наукова стаття присвячена дослідженню актуального питання правової протидіі дифамаційним проявам, тобто поширенню неправдивих відомостей, які ображають особу й заподіюють шкоду їі честі, гідності й діловій репутації. Разом із тим здійснення приватних прав особи і їхній захист не повинні обмежувати основоположне право особи на самовираження, публічне висловлювання своїх поглядів, думок та ідей. Саме в цьому за критеріями демократичної міжнародної спільноти полягає належна реалізація цивілізаційного права на свободу власного волевиявлення. Суди під час вирішення відповідних справ повинні забезпечувати баланс між конституційним правом на свободу думки й слова та правом на повагу до людської гідності.

Ключові слова: дифамачія, право на приватність, свобода вираження поглядів.
\end{abstract}

Предложенная научная статья посвящена исследованию актуального вопроса правового противодействия диффамационным проявлениям, то есть распространению ложных сведений, оскорбляющих личность и наносящих вред чести, достоинству и деловой репутации. Вместе с тем осуществление приватных прав личности и их защита не должны ограничивать основополагающее право человека на самовыражение, публичное высказывание своих взглядов, мыслей и идей. Именно в этом по критериям демократического международного сообщества заключается надлежащая реализация цивилизационного права на свободу собственного волеизъявления. Суды при разрешении соответствующих дел должны обеспечивать баланс между конституционным правом на свободу мысли и слова и правом на уважение $к$ человеческому достоинству.

Ключевые слова: диффамация, приватность, свобода выражения взглядов.

Guyvan P. D. The issue of legal separation of defamation from acceptable criticism in the media

The proposed scientific article is devoted to the study of the topical issue of legal counteraction to defamation, ie the dissemination of false information that offends a person and harms his honor, dignity and business reputation. At the same time, the exercise of a person's private

(с) Гуйван П. Д., 2020 rights and their protection should not limit the fundamental right of a person to self-expression, public expression of their views, opinions and ideas. Numerous legal mechanisms are used to implement these powers by the media and specific people who disseminate their views through them, including the opportunity to publicly cover not only facts that are perceived by society and characters as tolerant information, but also those that contain criticism, sometimes - reasonable insults, data that are shocking or contain a negative assessment of personality. According to the criteria of the democratic international community, this is the proper realization of the civilizational right to freedom of expression. In fact, this is the modern conflict between the right to self-expression and the right of a particular person to privacy, which is protected by the rule of Art. 8 of the Convention for the Protection of Human Rights and Fundamental Freedoms. Given the "duties and responsibilities"inherent in the exercise of freedom of expression, the guarantee of freedom of expression of matters of general interest is subject to the proviso that they act in good faith to provide accurate and reliable information in accordance with the ethics of journalism. One of the most common violations in the field of media activity is the disclosure of defamatory information, ie the dissemination of unreliable information about a person, which degrades his honor and dignity, damages his business reputation. In this case, the right to freely express one's thoughts and views may be limited. But such restrictions must be based on the principles of civilization: interference must be prescribed by law, have a legitimate aim and be necessary in a democratic society. In resolving relevant cases, the courts must strike a balance between the constitutional right to freedom of thought and speech and the right to respect for human dignity.

Key words: defamation, right to privacy, freedom of expression.

Постановка проблеми та її актуальність. Право на інформацію є складовою частиною права на самовираження, а відтак - особистим правом кожного [1, с. 52]. Воно реалізується через можливість вільно, без перешкод з боку держави та інших установ, висловлювати, у тому числі через засоби масової інформації, пресу, свої погляди, переконання й думки. Для реалізації вказаних повноважень залучаються численні юридичні механізми 
демократичного штибу, серед яких можливість висвітлювати публічно не лише факти, які сприймаються суспільством і персонажами як толерантні відомості, але й такі, що містять критику, іноді обґрунтовану образу, дані, що шокують або містять негативну оцінку особистості. Саме в цьому за критеріями демократичної міжнародної спільноти полягає належна реалізація цивілізаційного права на свободу власного волевиявлення. Водночас свобода слова має ту ваду, що вона може призвести до порушення приватних прав особи, зокрема на честь, гідність і ділову репутацію. Якраз у цьому проявляється сучасна колізія між правом на самовираження та правом конкретної людини на приватність, що охороняється правилом ст. 8 Конвенції про захист прав людини й основоположних свобод (далі - Конвенція). Ці два основні права особи досить часто вступають у суперечність, тож маємо визначити критерії їх розмежування й ознаки застосування. Встановлюючи межі реалізації права на свободу слова, необхідно передусім забезпечити правовий захист особистих нематеріальних прав суб'єктів, стосовно яких поширюється інформація. Свого часу Верховний Суд України у своїй постанові надав тлумачення застосування відповідного законодавства. За його змістом праву на свободу думки й слова, на вільне вираження своїх поглядів і переконань відповідає обов'язок не поширювати недостовірну інформацію й таку, що ганьбить гідність, честь чи ділову репутацію. Тому суди під час вирішення відповідних справ повинні забезпечувати баланс між конституційним правом на свободу думки й слова, правом на вільне вираження своїх поглядів і переконань, з одного боку, та правом на повагу до людської гідності, конституційними гарантіями невтручання в особисте життя, судовим захистом права на спростування недостовірної інформації, на відповідь і заборону поширення інформації, якою порушуються особисті немайнові права тощо, з іншого [2, п. 1]. Отже, позаяк питання не $є$ однозначним, воно вельми актуальне й повсякчас турбує свідомість громадян.

Аналіз останніх досліджень i публікацій. У науковій літературі стан проблематики в досліджуваному питанні вивчався такими вченими, як В. Тацій, Ю. Тодика, О. Крупчан, Н. Ортинська, М. Муратов, С. Кравченко, І. Арістова, Г. Почепцов, О. Кохановська, В. Шамрай, М. Дженіс та інші. Однак зазвичай вказані дослідження в основному спрямовані на загальну характеристику такого чинника основоположних свобод людини, як можливості мати вільний доступ до засобів вираження своїх думок - засоби масової інформації (далі -
3МI). Водночас відсутній серйозний аналіз питань щодо причин і підстав обмежень цього права задля охорони приватності людини. Практично недослідженою в доктринальній площині залишається проблематика оцінювання судами відмінностей між фактами й судженнями, не встановлені критерії визначення балансу між необхідністю захисту публічного права на висловлення поглядів і охороною приватності особи, зокрема їі честі й ділової репутації. Потребують більш прискіпливого дослідження питання практики застосування Європейським судом з прав людини (далі - ЄСПЛ, Суд) положень ст. 10 Конвенції та адаптації відповідних правових підходів до правозастосування українським судівництвом.

Метою статті $€$ доктринальне напрацювання юридичних підходів щодо ефективності застосування європейського принципу свободи вираження поглядів.

Виклад основного матеріалу. На засоби масової інформації покладено обов'язок поширювати інформацію та ідеї, що стосуються питань, які становлять суспільний інтерес. Крім того, що в преси $\epsilon$ завдання передавати таку інформацію та ідеї, громадськість також має право їх отримувати. Європейський суд стоїть на позиції, що журналістська свобода включає також і можливість вдатися до певної міри перебільшення або навіть провокації [3, п. 58]. Журналіст також має право на вибір способу вираження. Суду й органам влади не личить підміняти в цьому питанні судження преси щодо того, до якої техніки репортажу слід вдаватися. Крім змісту висловлення ідей і інформації, ст. 10 захищає також їхню форму передавання [4, п. 39]. Однак ст. 10 Конвенції не гарантує необмежену свободу вираження поглядів навіть стосовно висвітлення в пресі питань, що викликають серйозне занепокоєння. У своїй діяльності мас-медіа й журналісти не повинні забувати, що основна мета свободи слова - створення простору для формування освіченого й поінформованого соціуму, спроможного самостійно оцінювати стан справ у суспільстві. Водночас $3 \mathrm{MI}$ не повинні перевищувати межі, накладені в інтересах захисту охоронюваних законом інтересів. Згідно з п. 2 конвенційної ст. 10, здійснення свободи преси покладає на неї певні обов'язки. Ці обов'язки й відповідальність за їх недотримання можуть набути значущості, коли виникає питання нападу на репутацію й підриву «прав інших людей».

Зважаючи на «обов'язки й відповідальність», притаманні здійсненню свободи вираження поглядів, гарантія, яка надається ст. 10 журналіс- 
там стосовно доповідей з питань, що становлять загальний інтерес, підпадає під застереження, що вони діють добросовісно з метою надавати точну й достовірну інформацію відповідно до етики журналістики. Одним з найтиповіших порушень у сфері діяльності 3MI є оприлюднення дифамаційних (diffamare - поширювати плітки) відомостей, тобто поширення про особу недостовірної інформації, яка принижує іï честь і гідність, завдає шкоди діловій репутації. Інформація, віднесена до категорії дифамаційної, повинна мати три складники: форму оприлюднення, характер опублікованої інформації та мотиви, що спричинили до поширення відповідних відомостей [5, с. 571]. У такому випадку право на вільне висловлювання своїх думок і поглядів може бути обмежене. Але подібні обмеження мають обов'язково ґрунтуватися на цивілізаційних засадах: втручання повинно бути передбачене законом, мати легітимну мету й бути необхідним у демократичному суспільстві. Отже, для того щоб визначити, чи втручання базувалося на достатніх причинах, які зробили його «необхідним», слід враховувати аспект суспільних інтересів справи. Занадто жорсткий і неадекватний контроль, неспівмірне втручання в інформаційне право з боку національного органу здатні відмовити участь преси в дебатах із питань, що мають законний суспільний інтерес [6, п. 35].

Як бачимо, демократичні принципи, закладені в Конвенцію, включають вимогу про пропорційність втручання, аналіз свободи преси, передбачуваність правової норми. Подібна оцінка законності державного втручання, за прецедентною позицією Європейського суду, має щоразу проводитись і під час розгляду справ про дифамацію. Водночас, вирішуючи питання про визнання поширеної інформації недостовірною, суди повинні визначати характер такої інформації та з'ясовувати, чи є вона фактичним твердженням, чи оцінним судженням. В цьому плані Україна зараз проходить тернистий і тривалий шлях. Показовим у ньому був розгляд Європейським судом з прав людини справи «Українська пресгрупа» проти України», в якій наша держава була визнана порушником права на свободу слова [7]. Це відбулося, як вказує ЄСПЛ, тому, що на момент оскаржуваних подій українське законодавство з дифамації не проводило різниці між оціночними судженнями й фактами, оскільки в ньому говорилося лише про загальні «відомості» й воно виходить із припущення, що будь-яке твердження підлягає доведенню за правилами цивільного судочинства. Зазвичай, якщо було порушено право на добру репутацію особи, навіть якщо наклеп був оціночним судженням, суди все одно вважали за потрібне призначити компенсацію моральної шкоди. (п. 59, 61, 62).

Крім того, у рішенні Європейського суду з прав людини в цій справі також вказується, що українське цивільне законодавство дає суперечливе визначення поняття дифамації, що може тлумачитися по-різному, оскільки містить подвійну вимогу. Висловлювання в засобах масової інформації має бути неправдивим і завдавати шкоду репутації для того, щоб вважатися дифамаційним відповідно до міжнародних стандартів дифамації. Проте це передбачає також захист від завдання шкоди іншим «інтересам», які $\epsilon$ надто неточно сформульовані та, отже, відкриті для інтерпретації й можливого зловживання нею: інші інтереси, такі, як приватність, повинні бути захищені завдяки окремим статтям, тоді як мала кількість можливих випадків дифамації мають бути чітко й вузько визначені (п. 36). Європейський суд з прав людини також критично оцінив правило, за яким негативна інформація про особу вважається недостовірною. «Негативна інформація» розуміється як будь-яка форма критики особи або представлення ії в негативному світлі. Цей пункт $\epsilon$ не лише порушенням права на свободу вираження, але й настільки його викривлює, що правдива, проте негативна інформація вважатиметься недостовірною. Це не може бути виправдано як необхідність, оскільки досить часто інтересам громадськості буде відповідати поширення негативних фактів і суджень про людей. Викриття фактів корупції, наприклад, вимагатиме й того, й іншого. Відтак Суд дійшов висновку, що законодавство України не мало чітких формулювань щодо цього питання, а це не дало можливості місцевим судам розрізнити критичні висловлювання, справедливі коментарі та заяви, які не потребували доведення. Таким чином, законодавство України містило негнучкі елементи, що могли призвести до прийняття рішень, несумісних зі ст. 10 Конвенції (п. 62).

Таким чином, національне право виходило з того, що захист честі, гідності й репутації публічної особи переважує можливість відкритої критики щодо нього/неї. Тож, Суд дійшов висновку, що українське право й практика чітко запобігали тому, щоб суди розрізняли оціночні судження, справедливі коментарі чи твердження, що не піддаються доказуванню. Між тим, оцінюючи сутність справи, Суд установив, що публікації містили критику двох політиків, яка була викладена жорсткою, полемічною, саркастичною мовою. Немає 
сумніву, що для позивачів вони були образливими й навіть шокуючими, Проте, обираючи свою професію, вони залишили себе відкритими для суворої критики й пильного нагляду; це той тягар, який політики мають прийняти в демократичному суспільстві. Відтак Суд вирішив, що українські суди перейшли межу розсуду, надану національним органам Конвенцією. Визнання заявника винним у наклепі було вочевидь непропорційним меті, що переслідувалась (п. 68).

3 урахуванням цієї та інших подібних справ щодо України національна влада, виконуючи правило ст. 13 Закону України «Про виконання рішень та застосування практики Європейського суду з прав людини», вжила заходи загального характеру з метою забезпечення додержання державою положень Конвенції, порушення яких встановлене Рішенням ЄСПЛ, забезпечення усунення недоліків системного характеру, які лежать в основі виявленого Судом порушення, а також усунення підстави для надходження до Суду заяв проти України, спричинених проблемою, що вже була предметом розгляду в Суді. Було внесено зміни до чинного цивільного законодавства. Наразі відповідно до ст. 30 Закону України «Про інформацію» ніхто не може бути притягнутий до відповідальності за висловлення оціночних суджень. Оціночними судженнями, за винятком наклепу, є висловлювання, які не містять фактичних даних, критика, оцінка дій, а також висловлювання, що не можуть бути витлумачені як такі, що містять фактичні дані, зокрема, з огляду на характер використання мовно-стилістичних засобів (вживання гіпербол, алегорій, сатири). Оціночні судження не підлягають спростуванню й доведенню їхньої правдивості. Інакше кажучи, людина не може нести відповідальність за вираження своєї думки. Своєю чергою думка визначається як вислів, у якому або не міститься твердження фактів, що можна довести як такі, що не відповідають дійсності, або який ніяк не можна тлумачити як такий, в якому йдеться про реальні факти, зважуючи на всі обставини, включаючи використану мову (риторика, гіпербола, сатира або жарт).

Таким чином, відповідно до ст. 277 Цивільного кодексу України (далі - ЦК) не є предметом оскарження в суді оцінні судження, думки, переконання, критична оцінка певних фактів і вад, що, як вираження суб'єктивної думки і поглядів відповідача, не можна перевірити на предмет їхньої відповідності дійсності (на відміну від перевірки істинності фактів) і спростувати. Це відповідає прецедентній судовій практиці Європейського суду з прав людини під час тлумачення положень ст. 10 Конвенції. Водночас, якщо особа вважає, що оціночні судження або думки принижують іiі гідність, честь чи ділову репутацію, а також порушує інші особисті немайнові права, вона вправі скористатися наданим їй законодавством правом на відповідь, а також на власне тлумачення справи в тому самому засобі масової інформації 3 метою обґрунтування безпідставності поширених суджень, надавши їм іншу оцінку. Якщо суб'єктивну думку висловлено в брутальній, принизливій чи непристойній формі, що принижує гідність, честь чи ділову репутацію, на особу, яка в такий спосіб висловила думку або оцінку, може бути покладено обов'язок відшкодувати завдану моральну шкоду.

У практичній площині питання захисту від дифамації в Україні наразі регулюються на підставі положень Постанови Пленуму Верховного Суду України «Про судову практику у справах про захист гідності та честі фізичної особи, а також ділової репутації фізичної та юридичної особи» від 27 лютого 2009 р. № 1, де вказується, що під час розгляду справ зазначеної категорії суди повинні мати на увазі, що юридичним складом правопорушення, наявність якого може бути підставою для задоволення позову, є сукупність таких обставин: а) поширення інформації, тобто доведення іï до відома хоча б однієї особи в будь-який спосіб; б) поширена інформація стосується певної фізичної чи юридичної особи, тобто позивача; в) поширення недостовірної інформації, тобто такої, яка не відповідає дійсності; г) поширення інформації, що порушує особисті немайнові права та завдає шкоди відповідним особистим немайновим благам або перешкоджає особі повно та своєчасно здійснювати своє особисте немайнове право. Під поширенням інформації слід розуміти: опублікування їі у пресі, передання по радіо, телебаченню чи з використанням інших засобів масової інформації; поширення в мережі Інтернет чи з використанням інших засобів телекомунікаційного зв'язку; викладення в характеристиках, заявах, листах, адресованих іншим особам; повідомлення в публічних виступах, в електронних мережах, а також в іншій формі хоча $б$ одній особі. Недостовірною вважається інформація, яка не відповідає дійсності або викладена неправдиво, тобто містить відомості про події та явища, яких не існувало взагалі або які існували, але відомості про них не відповідають дійсності (неповні або перекручені). Згідно з частиною третьою ст. 277 ЦК негативна інформація, поширена 
про особу, вважається недостовірною, якщо особа, яка iii поширила, не доведе протилежного (презумпція добропорядності). Негативною слід вважати інформацію, у якій стверджується про порушення особою, зокрема, норм чинного законодавства, вчинення будь-яких інших дій (наприклад, порушення принципів моралі, загальновизнаних правил співжиття, неетична поведінка в особистому, суспільному чи політичному житті тощо) і яка, на думку позивача, порушує його право на повагу до гідності, честі чи ділової репутації [2, п. 15].

Та попри оновлення матеріального законодавства в коментованій царині практика його застосування ще не перебуває на належному рівні. Продовжують залишатися неоднозначними судові оцінки дифамаційних проявів інформаційних повідомлень, в першу чергу негативного змісту. Зокрема, це стосується неможливості визначення судами різниці між оціночними судженнями та фактами. Водночас ЄСПЛ цій проблематиці також приділяє підвищену увагу й напрацював усталені підходи. Так, він вказує, що критична оцінка фактів не може слугувати підставою для задоволення позовів щодо моральної шкоди [8, п. 17-19]. А в конкретних справах рішуче відмежовує особисті думки осіб, які критикують владу та публічних персон, від спотворення фактів і обставин спору. Так, у справі «Торгерсон проти Ісландії» [9] заявник у двох своїх статтях звинуватив поліцію у жорстокості. Публікації в пресі викликали масштабну дискусію з проблеми взаємин між суспільством і поліцією. У статтях автором були використані такі вирази: «звірі в уніформі», «поліцейська нічна команда Рейк'явіка», «жертви поліцейського свинства», «тварини й садисти». Поліцейська Асоціація Рейк'явіка попросила прокурора дослідити вищезгадані твердження. В обвинувальному акті ці висловлювання були розцінені як дифамаційні заяви. Заявник був засуджений до виплати штрафу в розмірі 10000 крон.

Під час розгляду справи по суті ЄСПЛ не погодився з аргументами уряду про те, що твердження в статтях заявника не мають достатніх об'єктивних і фактичних підстав. У першій статті за відправну точку взято один конкретний випадок жорстокості (справа Скафте Йонссона), який викликав широку полеміку і привів до обвинувального вироку щодо поліцейського, з чиєї вини все сталося. Щодо інших фактичних даних, що містяться в статтях, Суд звертає увагу, що вони складалися по суті з посилань на «істо- рії» або «чутки», які виходять від інших людей, а не від заявника, або на «громадську думку», включаючи твердження про жорстокість поліції. Наприклад, це були сусіди по кімнаті молодої людини в лікарні, які розповіли, і працівники лікарні, які підтвердили, що йому було завдано травм поліцією. При цьому не було встановлено, що ця «історія» в цілому не відповідає дійсності і була просто вигадана. Знову ж таки відповідно до першої статті заявник з'ясував, що більшості людей були відомі різні історії подібного змісту, які були настільки схожі й численні, що їх навряд чи можна сприймати як звичайну брехню. Заявник по суті повідомляв те, що говорилося іншими щодо жорстокості поліції. Він був засуджений Кримінальним судом Рейк'явіка за порушення за ст. 108 Кримінального кодексу, почасти через нездатність підтвердити те, що було визнано його власними твердженнями. Але, коли від заявника вимагали довести правдивість його тверджень, на думку Суду, його ставили перед невідповідним, якщо не нездійсненним, завданням.

Суд також не впевнений, що основною метою заявника було підірвати репутацію поліції Рейк'явіка в цілому. По-перше, його критика не могла бути прийнята як нападки щодо всіх працівників, або будь-якого певного працівника поліції Рейк'явіка. У першій статті заявник передбачає, що «порівняно невелика кількість індивідів $\epsilon$ винуватцями» і що, «будемо сподіватися, в результаті розслідувань комітету виявиться, що винуватці - лише крихітна жменька окремих поліцейських». По-друге, заявник по суті повідомляв те, що говорилося іншими. Ці обставини в сукупності з уважним прочитанням першої статті підтверджують його твердження, що основна мета полягала в тому, щоб спонукати міністра юстиції до створення незалежного й неупередженого органу для проведення розслідувань скарг із приводу жорстокості поліції. Статті стосуються питань великої суспільної ваги, що загалом не було оскаржено. Це правда, що обидві статті написано в дуже міцних виразах. Однак, приділяючи належну увагу їхній цілі та дії, для яких вони писалися, Суд дотримується думки, що використовувана в статтях мова не може бути розцінена як надмірна. Відтак Суд вважає, що визнання заявника винним і обвинувальний вирок можуть перешкодити відкритості дискусії зі суспільно значущих питань. Посилаючись на вищесказане, Суд дійшов висновку, що доводи, висунуті урядом, не $є$ достатніми, щоб показати, що втручання, з приводу якого 
була заявлена скарга, відповідало законній меті. Таким чином, воно не було «необхідним у демократичному суспільстві». Відповідно, мало місце порушення ст. 10 Конвенції (п. 65-70).

Висновки. Безумовно, під час розгляду спірних питань про дифамацію в першу чергу органам, що їх розглядають, слід знайти необхідну рівновагу між реалізацією права на свободу вираження поглядів і компенсацією шкоди, завданої репутації особи. Водночас будь-яке обмеження права на свободу вираження поглядів або інформації, навіть задля охорони репутації інших людей, не може бути виправдано, якщо не доведено переконливо його необхідність у демократичному суспільстві. Зокрема, обмеження $\epsilon$ безпідставним, якщо за даних обставин реально наявні менш обтяжувальні й доступні засоби законного захисту приватності. Також не може застосовуватися державне втручання у свободу слова, якщо, зважаючи на всі обставини, обмеження виявиться невідповідним через те, що користь захисту репутації не набагато переважить шкоду, завдану свободі вираження поглядів.

\section{Література}

1. Кушакова Н. Конституційне право на інформацію в Україні: сучасний період. Право України. 2002. № 12. С. 51-55.

2. Про судову практику у справах про захист гідності та честі фізичної особи, а також ділової репутації фізичної та юридичної особи. Постанова Пленуму Верховного Суду України від 27 лютого 2009 р. № 1. URL: https://zakon.rada.gov.ua/laws/ show/v_001700-09\#Text.
3. Рішення ЄСПЛ від 21 грудня 2004 р. у справі «Бусуйок проти Молдови» (Busuioc v. Moldova). URL: http: / / eurocourt.in.ua/Article.asp?Aldx=748.

4. Рішення ЄСПЛ від 11 січня 2000 р., остаточне від 11 квітня 2000 р. у справі News Verlags GmbH \& CoKG v.Austria, заява № 31457/96. URL: https:// hudoc.echr.coe.int/eng\#\{"itemid":["001-58587"]\}.

5. Veeder V. V. The History and Theory of the Law of Defamation. Columbia Law Review. 1903. Vol. 3, № 8. Р. 546-573.

6. Рішення ЄСПЛ від 23 вересня 1994 р. у справі «Джерсільд проти Данії» (Jersild v Denmark), заява № 15890/89. URL: https://www.hr-dp.org/ files/2013/09/09/CASE_OF_JERSILD_v._DENMARK_.pdf.

7. Рішення ЄСПЛ від 29 березня 2005 р. у справі «Українська пресгрупа» проти України», заява № 72713/01, URL: http://zakon3.rada.gov.ua/laws/ show/980_382.

8. Рішення ЄСПЛ від 19 жовтня 2004 р. у справі «Мараслі проти Туречччини» (Marasli v. Turkey), заява № 40077/98, URL: http://www.preview2.1cor. enstar.net/1315/?form_1155. replyids $=602$.

9. Рішення ЄСПЛ від 25 червня 1992 р. у справі «Торгерсон проти Ісландії» (Thorgeir Thorgeirson v. Iceland), заява № 13778/88. URL: http:// www. humanrights.is/static/files/Itarefni/torgeir_ torgeirson_gegn_islandi.pdf.

Гуйван П. Д., кандидат юридичних наук, заслужений юрист України, професор

Полтавського інституту бізнесу Міжнародного науково-технічного університету імені академіка Юрія Бугая 